\title{
Bioprocessing of Soft Cereals for Postmodern Ruminants: Ascertaining Decades of Uncertainty
}

\author{
Akbar Nikkhah* \\ Chief Highly Distinguished Professor, Department of Animal Sciences, University of Zanjan, Iran
}

*Corresponding author: Akbar Nikkhah, Chief Highly Distinguished Professor, Department of Animal Sciences, Faculty of Agricultural Sciences, University of Zanjan, Zanjan, Iran, Tel: +98-24-330-528-01; Fax: +98-24-330-532-02; E-mail: nikkhah@znu.ac.ir

Rec date: Nov 13, 2014, Acc date: Nov 13, 2014, Pub date: Nov 17, 2014

Copyright: (C) 2014 Nikkhah A. This is an open-access article distributed under the terms of the Creative Commons Attribution License, which permits unrestricted use, distribution, and reproduction in any medium, provided the original author and source are credited.

\section{Editorial}

This article provides practical thoughts and on-farm strategies to seek relief from decades of confusions in optimizing physical bioprocessing of soft cereal grains for ruminants. Soft grains mostly include wheat, barley and oats that are characterized by their rapidly degradable starch and protein in rumen [1,2]. The problems start from such initial over-fermentation shortly post-feeding. However, despite decades of research, less than few simple and feasible approaches have been developed for on-farm application. This is critical since the metabolic disorders (e.g., subacute rumen acidosis, steatosis, steatohepatitis, and immune deficiency) stem from irregular and abnormal rhythms of circadian rumen fermentation $[3,4]$.

The above disorders greatly reduce ruminant longevity and profitability. Soft grains have long been rolled either dry or using steam in many parts of the world. With advanced technologies, complex steam-rolling and steam-flaking equipment have been established to replace the more traditional bioprocessing technique of grinding using hammer mills. However, problems have not been prevented or resolved and were even worsened in many world scenarios $[5,6]$. This proves that new technologies do not necessarily bring or improve management. In reality, the advanced technologies have made the challenges more complicated than they were before, mainly due to mismanagement in their optimization methods.

Evidence and experience from Iran, North and South Americas, Europe, Asia and Australia suggest that the modern ruminant industry has not suffered from any other risk more than mismanagement in bioprocessing and feeding of soft cereals [4,7]. Research findings indicate that increasing grain particle size by dry-rolling, steamrolling, or steam-flaking, when compared to fine and coarse grinding, does not essentially improve productivity and health. Since many farms worldwide have medium or small size, establishing the expensive rolling facilities do in reality provide no advantage over grinding and could greatly increase costs. Such energy-consuming bioprocessing techniques may be justified merely when used in very large farms ( $>$ 500-1000 heads) to help better manage diet mixing and healthy feeding, and reduce feed waste and diet misrepresentation.
As a certainty, the conventional grinding of soft cereals is a viable and economical strategy to improve postmodern ruminant management and economics. More advanced and complex bioprocessing technologies would only exacerbate the problems in many global scenarios. They ought to be utilized in right place at right time e.g., in large-scale farming at moderately high grain rates. When dietary inclusions rates follow wisdom, the choice of bioprocessing techniques must not be a challenge.

\section{Acknowledgments}

Thanks to the Iranian Ministry of Science Research and Technology, National Elite Foundation, Tehran, and University of Zanjan for supporting the author's global programs of optimizing science edification.

\section{References}

1. Nikkhah A (2012) Postmodern management of starchy grains for ruminants: A barley grain perspective. Rus Agric Sci 38: 14-21.

2. National Research Council (2001) Nutrient Requirements of Dairy Cattle. 7th revised edition. National Academy Press, Washington, D.C., USA.

3. Nikkhah A (2014) Bioprocessing of barley for food-producing ruminants: A workable dilemma. J Biprocess Biotechniq 4: el13.

4. Nikkhah A (2012) Barley grain for ruminants: A global treasure or tragedy. J Anim Sci Biotechnol 3: 22.

5. Nikkhah A (2011) Barley grain for rumen and ruminants: overmodernized uses of an inimitable fuel. Barley: Production, Cultivation and Uses. Edited by Elfson SB. Nova Science Publishers, Inc., NY, USA, 2011a: 247-258.

6. Nikkhah A (2011) Optimizing barley grain use by dairy cows: a betterment of current perceptions. Progress in Food Science and Technology. Volume 1. Edited by Greco AJ. Nova Science Publishers, Inc, NY, USA, 2011b: 165-178.

7. Nikkhah A (2014) Steam bioprocessing philosophy of cereals for ruminants: Time for a new history. J Bioprocess Biotech 4: e114. 